\title{
The predictive value of multiple electrode platelet aggregometry for postoperative bleeding complications in patients undergoing coronary artery bypass graft surgery
}

\author{
Sebastian Woźniak ${ }^{1}$, Karolina Woźniak², Tomasz Hryniewiecki ${ }^{3}$, Mariusz Kruk ${ }^{4}$, Jacek Różański \\ Mariusz Kuśmierczyk ${ }^{1}$ \\ ${ }^{1}$ Department of Cardiac Surgery and Transplantology, Institute of Cardiology in Warsaw, Warsaw, Poland \\ 2Department of Clinical Biochemistry and Pharmacology, Institute of Cardiology in Warsaw, Warsaw, Poland \\ ${ }^{3}$ Department of Acquired Cardiac Defects, Institute of Cardiology in Warsaw, Warsaw, Poland \\ ${ }^{4}$ Department of Coronary and Structural Heart Diseases, Institute of Cardiology in Warsaw, Warsaw, Poland
}

Kardiochirurgia i Torakochirurgia Polska 2016; 13 (1): 3-9

\begin{abstract}
Introduction: Postoperative bleeding is one of the most serious complications of cardiac surgery and requires transfusion of blood or blood products. Acetylsalicylic acid (ASA) and clopidogrel (CLO) are the two most commonly used antiplatelet agents; when used in combination (i.e., as dual antiplatelet therapy [DAPT]), they exert a synergistic effect. Dual antiplatelet therapy, however, significantly increases the risk of postoperative bleeding. The effect of antiplatelet therapy can be monitored by platelet aggregation testing. One of the most commonly methods used for assessing platelet reactivity is multiple electrode aggregometry (MEA) which can be performed with the use of Multiplate analyzer. Although the method has long been used in interventional cardiology to assess the effect of antiplatelet therapy, it is not available at cardiac surgery departments as a standard diagnostic procedure. The aim of the study was to establish the frequency of bleeding complications following coronary artery bypass graft (CABG) surgery in patients on single antiplatelet therapy (SAPT) and patients on DAPT and to determine the usefulness of routine measurement of platelet responsiveness before CABG surgery in patients receiving antiplatelet therapy.

Material and methods: A consecutive cohort of 200 patients referred for elective surgical treatment of stable coronary artery disease was enrolled (100 consecutive patients on SAPT [ASA $75 \mathrm{mg} /$ day] and 100 consecutive patients on DAPT [ASA $75 \mathrm{mg} /$ day + CLO $75 \mathrm{mg} /$ day]). All subjects continued their antiplatelet therapy until the day before surgery. For each subject, platelet aggregation testing in the form of an ASPI test and an ADP test was performed on the Multiplate analyzer. Each subject underwent coronary artery bypass grafting surgery. For the primary and secondary endpoints in our study we adopted
\end{abstract}

\section{Streszczenie}

Wstęp: Krwawienie pooperacyjne jest jednym z najpoważniejszych powikłań po zabiegach kardiochirurgicznych i wymaga przetaczania krwi lub preparatów krwiopochodnych. Kwas acetylosalicylowy (acetylsalicylic acid - ASA) i klopidogrel (clopidogrel - CLO) są najczęściej stosowanymi lekami przeciwpłytkowymi; w połączeniu (tzn. jako podwójna terapia przeciwpłytkowa; dual antiplatelet therapy - DAPT) leki te wywierają efekt synergiczny. Niemniej jednak DAPT zwiększa znacząco ryzyko pooperacyjnego krwawienia. Efekty terapii przeciwpłytkowej można monitorować, badając agregację płytek krwi. Jedną z najczęściej stosowanych metod oceny reaktywności płytek jest agregometria impedancyjna (multiplatelet electrode aggregometry - MEA), którą można przeprowadzić przy użyciu analizatora Multiplate ${ }^{\circledR}$. Choć metoda ta od dłuższego czasu jest stosowana w kardiologii interwencyjnej do oceny efektów terapii przeciwpłytkowej, nie jest ona dostępna na oddziałach kardiochirurgicznych jako standardowa procedura diagnostyczna. Celem pracy było ustalenie częstości powikłań po operacjach pomostowania aortalno-wieńcowego (coronary artery bypass graft - CABG ) u pacjentów otrzymujących pojedynczą (single antiplatelet therapy - SAPT) lub podwójną DAPT (double antiplatelet therapy - DAPT) oraz zbadanie użyteczności pomiarów reaktywności płytek przed operacjami CABG u pacjentów otrzymujących terapię przeciwpłytkową.

Materiat i metody: Badanie objęło kohortę 200 pacjentów skierowanych na elektywny zabieg chirurgiczny stabilnej choroby wieńcowej [100 kolejnych pacjentów otrzymujących SAPT (ASA $75 \mathrm{mg} /$ dzień) i 100 kolejnych pacjentów otrzymujących DAPT (ASA 75 mg/dzień + CLO 75 mg/dzień)]. Wszyscy pacjenci kontynuowali terapię przeciwpłytkową do dnia poprzedzającego zabieg. Dla każdego z pacjentów dokonano pomiaru agregacji płytek w postaci testów ASPI i ADP, korzystając z analizatora

Address for correspondence: Sebastian Woźniak, Department of Cardiac Surgery and Transplantology, Institute of Cardiology in Warsaw, 42 Alpejska St., 04-628 Warsaw, Poland, phone:+48 604195 551, e-mail: woz-seb@o2.pl 
the definition provided in 'Standardised Bleeding Definitions for Cardiovascular Clinical Trials: A Consensus Report from the Bleeding Academic Research Consortium' ('Circulation', 2011) for BARC type 4 bleeding (i.e. CABG-related bleeding).

Results: An ROC curve was constructed for the ASPI test and ADP test for a total of 200 patients. No significant correlations were demonstrated between the ASPI test results and either the primary endpoint or the secondary endpoints. A correlation was found between the ADP test results and the composite primary endpoint and each of the secondary endpoints. The primary endpoint of major postoperative bleeding occurred in 16 subjects. From the ROC curve, we established the optimal cut-off value for the ADP test of $26 \mathrm{U}$ at sensitivity of $72 \%$, specificity of $69 \%$, positive predictive value of $69.90 \%$, and negative predictive value of $71.13 \%$.

Conclusions: In patients on antiplatelet therapy, an ADP test result of $<26 \mathrm{U}$ is strongly predictive of serious bleeding complications after CABG surgery. The MEA ADP test allows to identify the group of patients at an increased risk of postoperative bleeding.

Key words: postoperative bleeding, single and dual antiplatelet therapy, diagnostics, Multiplate, ASPI test, ADP test, coronary artery bypass grafting (CABG).
Multiplate. Wszyscy pacjenci zostali poddani operacji pomostowania aortalno-wieńcowego. Definicje pierwszorzędowego i drugorzędowych punktów końcowych zostały określone na podstawie pracy 'Standardised Bleeding Definitions for Cardiovascular Clinical Trials: A Consensus Report from the Bleeding Academic Research Consortium' ('Circulation', 2011) dla krwawienia typu 4 wg klasyfikacji BARC (tzn. krwawienia związanego z CABG).

Wyniki: Utworzono krzywą ROC dla testów ASPI i ADP przeprowadzonych u 200 pacjentów. Nie wykazano znaczących korelacji pomiędzy wynikami testu ASPI i pierwszorzędowym punktem końcowym lub drugorzędowymi punktami końcowymi. Odnaleziono korelację pomiędzy wynikami testu ADP i pierwszorzędowym punktem końcowym oraz każdym z drugorzędowych punktów końcowych. Pierwszorzędowy punkt końcowy w postaci istotnego krwawienia pooperacyjnego wystąpił u 16 badanych. Na podstawie krzywej ROC ustalono optymalną wartość odcięcia dla testu ADP na poziomie $26 \mathrm{U}$ przy czułości $72 \%$, specyficzności 69\%, pozytywnej wartości predykcyjnej 69,90\% i negatywnej wartości predykcyjnej 71,13\%.

Wnioski: U pacjentów otrzymujących leczenie przeciwpłytkowe wynik testu ADP < $26 \mathrm{U}$ jest silnym czynnikiem predykcyjnym dla powikłań krwotocznych po zabiegach CABG. Test ADP MEA pozwala na zidentyfikowanie grupy pacjentów o podwyższonym ryzyku krwawienia pooperacyjnego.

Słowa kluczowe: krwawienie pooperacyjne, pojedyncza i podwójna terapia przeciwpłytkowa (SAPT i DAPT), diagnostyka, Multiplate, test ASP, test ADP, pomostowanie aortalno-wieńcowe (CABG).

induced platelet activation. The inhibition of platelet function by CLO persists for about 7-10 days [2, 3]. When used in combination (i.e., as DAPT), ASA and CLO exert synergistic effects. Dual antiplatelet therapy, however, significantly increases the risk of postoperative bleeding [4]. The effect of antiplatelet therapy may be monitored by platelet aggregation testing. There is a considerable patient-to-patient variability in platelet responsiveness to the same antiplatelet regimen, ranging from very little or no inhibition of platelet aggregation (which is described as "non-response", "hyporesponsiveness", or "resistance") to profound inhibition of platelet aggregation ("hyper-responsiveness") [5-7].

Quantitative assessment of platelet aggregation is not, however, available at cardiac surgery departments as a standard diagnostic procedure; according to the guidelines on myocardial revascularization, measuring treatment response by platelet function assays should be limited to clinical research and should not be routinely used in clinical practice [8].

The aims of the study were as follows: to establish the frequency of bleeding complications following coronary artery bypass graft (CABG) surgery in patients on single antiplatelet therapy (SAPT) and patients on DAPT, to establish the usefulness of routine measurements of platelet responsiveness before CABG surgery in patients on antiplatelet therapy, to determine the cut-off value of the aggregometry test result that best discriminates patients at 
low risk from those at high risk of bleeding complications following CABG surgery, and to establish whether this cutoff value correlates with the risk of primary and secondary endpoints.

\section{Material and methods}

The study was approved by the Local Ethics Committee of the Institute of Cardiology and, given the fact that the study entailed a retrospective analysis of prospectively collected data, the requirement to obtain informed consent was waived by the Committee.

Recruitment started in 2012 and continued until a consecutive cohort of 200 patients referred for elective surgical treatment of SCAD was enrolled (100 consecutive patients on SAPT [ASA $75 \mathrm{mg} /$ day] and 100 consecutive patients on DAPT [ASA 75 mg/day + CLO 75 mg/day]).

Patients with thrombocytopenia (platelet count $<150,000$ cells $/ \mathrm{mm}^{3}$ ), abnormal coagulation test results (activated partial thromboplastin time [APTT] > $40 \mathrm{sec}$, international normalised ratio [INR] $>1.25$ ), current treatment with a GP IIb/IIla inhibitor, or a history of redo-CABG, as well as patients currently referred for CABG combined with valve surgery were excluded from the study [9].

The following variables were documented preoperatively in each subject: age, sex, laboratory parameters (red blood cell $[R B C]$ count, haematocrit, platelet [PLT] count, INR), left ventricular ejection fraction (LVEF) estimated by echocardiography, the number of implanted stents, and the following risk scores: the EuroSCORE, the logistic EuroSCORE, and the Society of Thoracic Surgeons (STS) mortality risk score.

The variables documented in each subject in the postoperative period included: chest tube drainage output, the number of units of packed red blood cells (PRBCs), PLT concentrate and fresh frozen plasma (FFP) transfused, whether re-exploration was required, whether the patient underwent (traditional) on-pump CABG (in which case two additional variables were documented: cardiopulmonary bypass time and aortic clamp time) or off-pump coronary artery bypass (OPCAB) surgery. Postoperative bleeding was assessed in terms of chest tube output in the first 24 hours after surgery, amount of blood and blood products transfused (PRBCS, PLT concentrate, FFP), and the need for chest re-exploration for bleeding. All the samples for laboratory tests were collected on the day before the surgery.

All the subjects continued their antiplatelet therapy until the day of sampling. The samples were processed and immediately analysed at the Department of Biochemistry and Clinical Pharmacology of our Institute. Two tests were performed in each subject: the ADP test and the ASPI test. Each subject underwent CABG. In each individual case, the decision whether to perform on-pump or off-pump surgery was left to the discretion of the operator, and, in either case, a standard surgical protocol for the respective type of CABG surgery was followed. The provision of general anaesthesia in both SAPT and DAPT subjects followed the same protocol.

\section{Laboratory methods}

Platelet aggregation testing was performed on a Multiplate analyzer (Roche Diagnostics, Mannheim, Germany) using the ASPI test and ADP test reagents to quantify the effects of ASA and CLO, respectively. Multiplate (short for 'multiple platelet function analyzer') is a multichannel analyzer of platelet reactivity, which performs the analysis on samples of whole blood. The principle underlying the method involves measuring the change of electric resistance occurring during platelet adhesion and aggregation to two electrodes, which is recorded by the analyzer over a period of six consecutive minutes. The result is presented graphically as an receiver operating characteristic (ROC) curve (with the resulting parameters being: aggregation and slope of the curve) $[10,11]$. The result is expressed as area under the curve (AUC). The reference ranges for healthy subjects given by the manufacturer were $51-117 \mathrm{U}$ for the ASPI test and 57-113 $U$ for the ADP test. The units we used were $U$ (not $\mathrm{AU} / \mathrm{min}$ as reported by Weber et al.), as recommended by the manufacturers in recent years $(U=A U / 10)$.

\section{Study endpoints}

For the primary endpoint in our study, we adopted the definition provided in 'Standardised Bleeding Definitions for Cardiovascular Clinical Trials: A Consensus Report from the Bleeding Academic Research Consortium' ('Circulation', 2011) for BARC type 4 bleeding (i.e., CABG-related bleeding). The primary endpoint was a composite endpoint of:

- perioperative intracranial bleeding within the first 48 hours post-op,

- re-operation after closure of sternotomy for the purpose of controlling bleeding,

Tab. I. Preoperative characteristics of the study cohort $(N=200)$

\begin{tabular}{|c|c|c|c|}
\hline & $\begin{array}{c}\text { ASA } \\
n=100\end{array}$ & $\begin{array}{c}\mathrm{ASA}+\mathrm{CLO} \\
n=100\end{array}$ & $p<0.05$ \\
\hline Age (years) & $64.46 \pm 9.029$ & $65.49 \pm 9.259$ & 0.599 \\
\hline Sex & M: 76, F: 24 & M: 77, F: 23 & 0.867 \\
\hline RBC $\left(10^{6} / \mu \mathrm{l}\right)$ & $4.611 \pm 0.967$ & $4.439 \pm 0.535$ & 0.546 \\
\hline PLT $\left(10^{3} / \mathrm{ml}\right)$ & $218.31 \pm 54.072$ & $226.02 \pm 81.487$ & 0.027 \\
\hline $\mathrm{HCT}(\%)$ & $40.188 \pm 4.258$ & $40.535 \pm 4.854$ & 0.174 \\
\hline INR & $1.058 \pm 0.759$ & $1.061 \pm 0.782$ & 0.743 \\
\hline EF pre-op (\%) & $51.80 \pm 9.936$ & $52.20 \pm 9.826$ & 0.787 \\
\hline EuroScore (\%) & $1.645 \pm 1.796$ & $2.263 \pm 3.793$ & 0.102 \\
\hline EuroScore Log. (\%) & $6.894 \pm 8.070$ & $9.628 \pm 11.502$ & 0.097 \\
\hline $\begin{array}{l}\text { ASPI (U) median } \\
\text { value }\end{array}$ & $13 \pm 12$ & $14 \pm 17$ & 0.907 \\
\hline $\begin{array}{l}\text { ADP }(U) \text { median } \\
\text { value }\end{array}$ & $52 \pm 23$ & $28 \pm 16$ & $<0.001$ \\
\hline $\begin{array}{l}\text { STS (re-OP risk } \\
\text { score) }\end{array}$ & $8.009 \pm 2.428$ & $8.836 \pm 4.195$ & 0.056 \\
\hline $\begin{array}{l}\mathrm{PCl}+\text { stent in } \\
\text { history }\end{array}$ & 18 & 40 & $<0.001$ \\
\hline
\end{tabular}

RBC - red blood cell, PLT - platelet, HCT - haematocrit, INR - international normalised ratio, EF - ejection fraction, STS - Society of Thoracic Surgeons, $\mathrm{PCl}$ - percutaneous coronary intervention 
- transfusion of 5 or more units of PRBCs within the first 48 hours post-op,

- chest tube output of $2000 \mathrm{ml}$ or more within the first 24 hours post-op.

Each of the above four events separately constituted a set of four secondary endpoints (with death being the fifth one) [12].

\section{Statistical methods}

Continuous variables were expressed as mean ( \pm standard deviation). The association between the preoperative variables and postoperative bleeding was assessed through preliminary univariate analysis using Student's $t$-test. Between-group differences in excessive bleeding and transfusions were explored with the Pearson $\chi^{2}$ test.

The correlation between the ASPI and ADP test results and the study endpoints were assessed by logistic regression. Adjustments for other potential factors related to the primary endpoint were made using multivariate logistic regression. Receiver operating characteristic curves were used to define an optimal cut-off point for the test result,

Tab. II. Surgical outcomes and transfusions in the cohort study. Testing for significant differences between the two study groups in the duration of mechanical ventilation and postoperative levels of serum creatinine and CK-MB was carried out using Student's $t$-test for independent variables and with the use of the Pearson $\chi^{2}$ test for the remaining variables

\begin{tabular}{|c|c|c|c|}
\hline & $\begin{array}{c}\text { ASA } \\
n=100\end{array}$ & $\begin{array}{c}\mathrm{ASA}+\mathrm{CLO} \\
n=100 \\
\end{array}$ & $\begin{array}{l}P<0.05 \\
\left(\text { test } \chi^{2}\right) \\
\end{array}$ \\
\hline OPCAB & 84 & 76 & 0.157 \\
\hline ECC & 19 & 24 & 0.410 \\
\hline Arterial grafts & 100 & 97 & 0.649 \\
\hline Venous grafts & 100 & 100 & 1.000 \\
\hline $\begin{array}{l}\text { Time of mechanical } \\
\text { ventilatory support (h) }\end{array}$ & $10.46 \pm 3.647$ & $20.83 \pm 77.480$ & 0.182 \\
\hline $\begin{array}{l}\text { Time of ICU ho- } \\
\text { spitalization (\% of } \\
\text { patients > } 2 \text { days) }\end{array}$ & $53 \%$ & $59 \%$ & 0.187 \\
\hline $\begin{array}{l}\text { Time of hospitaliza- } \\
\text { tion (\% of patients } \\
<7 \text { days) }\end{array}$ & $52 \%$ & $51 \%$ & 0.327 \\
\hline Creatinine post-op & $88.2 \pm 46.804$ & $90.45 \pm 34.401$ & 0.791 \\
\hline Infections & 7 & 12 & 0.335 \\
\hline CK-MB (> 308 U/I) & 23 & 28 & 0.420 \\
\hline $\begin{array}{l}10 \times \mathrm{Tnl}(\% \text { of pa- } \\
\text { tients) }\end{array}$ & $20.5 \%$ & $26.5 \%$ & $<0.001$ \\
\hline $\begin{array}{l}\text { Catecholamines } \\
\text { (\% of patients) }\end{array}$ & $29 \%$ & $38 \%$ & 0.178 \\
\hline Atrial Fibrillation & 25 & 26 & 0.875 \\
\hline RBC units & 60 & 73 & 0.071 \\
\hline FFP units & 91 & 92 & 1.0 \\
\hline PLT units & 56 & 92 & 0.026 \\
\hline
\end{tabular}

OPCAB - off-pump coronary artery bypass, ECC - extracorporal circulation, ICU - intensive care unit, CK-MB - creatine kinase-MB, Tnl - troponin I, RBC - red blood cell, FFP - fresh frozen plasma, PLT - platelet which best predicts the occurrence of a primary endpoint event. In order to study the impact of therapy on the correlation between platelet reactivity test results and the primary endpoint, an interaction test was performed. $P$ values below 0.05 were considered statistically significant.

\section{Results}

There were no statistically significant differences between the groups in terms of age, sex, or laboratory variables (RBC count, PLT count, haematocrit, INR). Coronary artery bypass graft procedures followed a standard protocol and the groups did not differ significantly with regard to the numbers of subjects undergoing on-pump versus off-pump surgery. In the DAPT group, there were three conversions to on-pump CABG, all due to hemodynamic instability. In both groups, similar numbers of arterial and venous bypass grafts were performed. The difference in the number of transfused PRBC and FFP units was not statistically significant. However, a statistically significant difference was found in the number of transfused units of PLT concentrate. The surgical outcomes are provided in Table II. Surgery results based on endpoints in the two study groups are provided in Figures 1 and 2.

\section{ASPI test results}

The impact of the ASPI test result in both groups was compared in all the 200 subjects. An ROC curve was constructed for the ASPI test for a total of 200 patients (Fig. 3). The result is expressed as AUC. The units we used were $U$ (not AU/min as reported by Weber et al. [13]), as recommended by the manufacturers in recent years $(U=A U / 10)$.

No significant associations were demonstrated between the ASPI test results and either the primary endpoint (95\% Cl: $0.48-0.63 ; p=0.460$ ) or the secondary endpoints

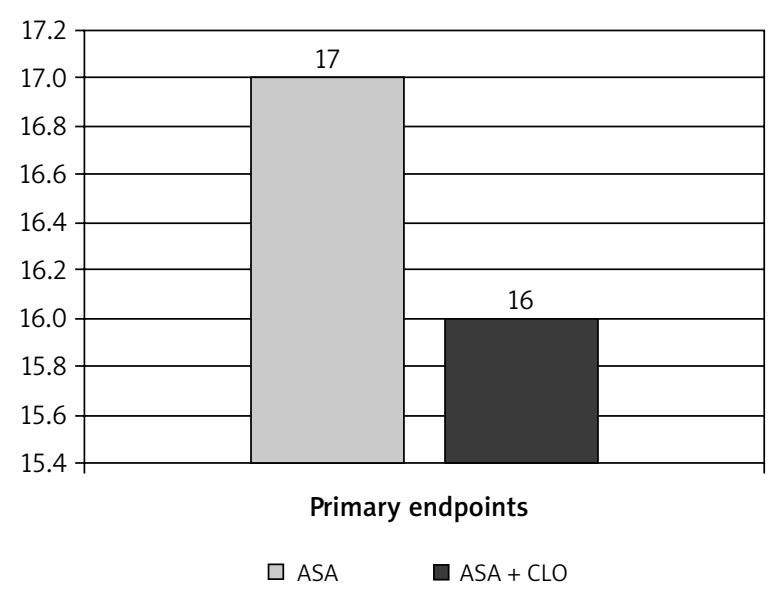

Fig. 1. Surgery results based on primary endpoints in the two study groups with $p=0.087$. The primary endpoint was a composite endpoint of: perioperative intracranial bleeding within the first 48 hours post-op, re-operation after closure of sternotomy for the purpose of controlling bleeding, transfusion of $\geq 5$ units of packed red blood cells (PRBCs) within the first 48 hours post-op, chest tube drainage $\geq 2000 \mathrm{ml}$ within the first 24 hours post-op 


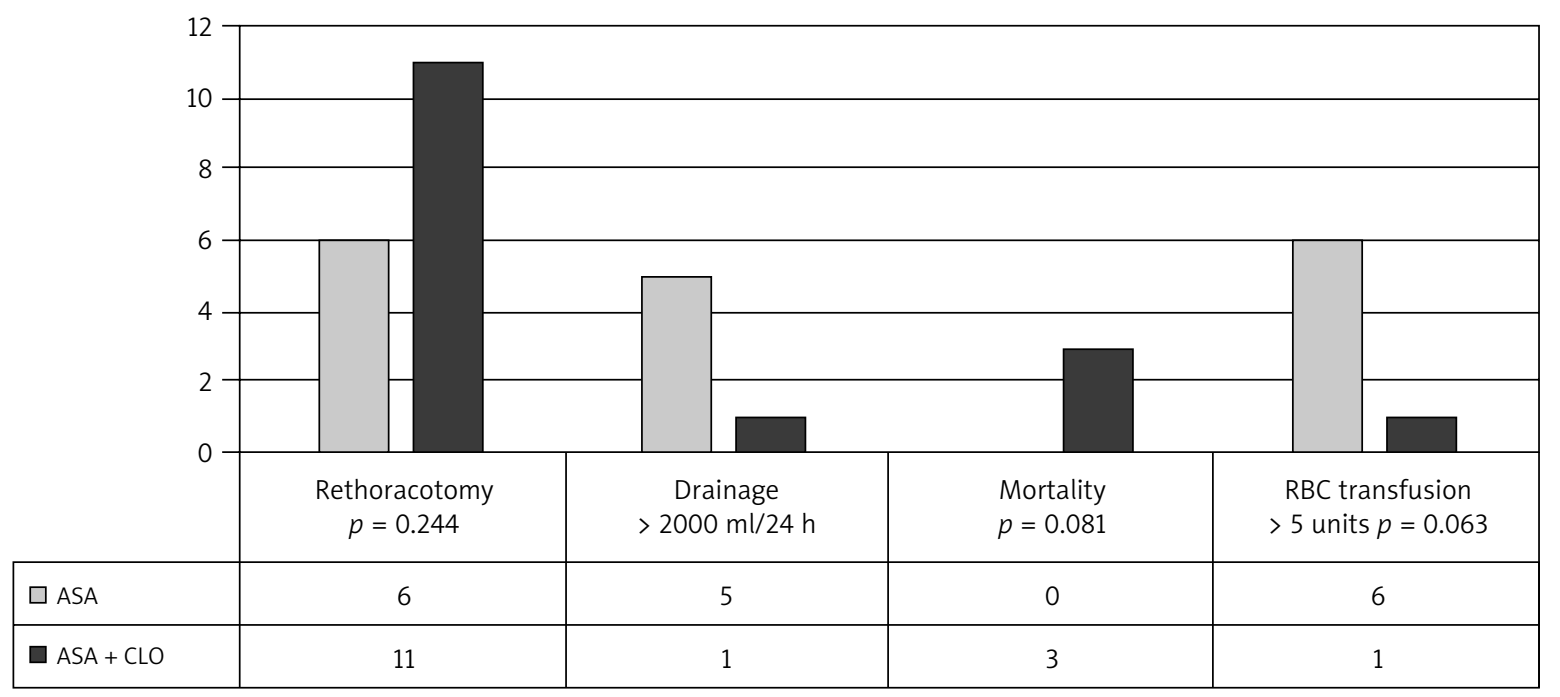

Fig. 2. Surgery results based on secondary endpoints in the two study groups

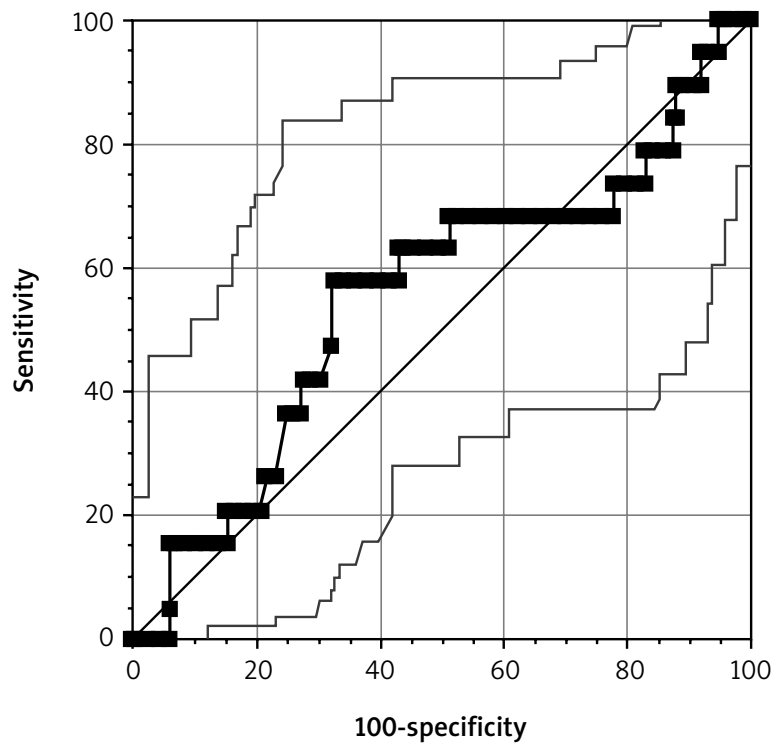

Fig. 3. An receiver operating characteristic (ROC) curve for the ASPI test results of the entire study cohort $(N=200)$

(95\% Cl: $0.509-0.650$ and $p=0.372$ for chest tube drainage output of $2000 \mathrm{ml}$ or more within the first 24 hours postop; $95 \% \mathrm{Cl}: 0.22$ and $p=0.210$ for transfusion of 5 or more units of PRBCs within the first 24 post -op: $95 \% \mathrm{Cl}$ : 153.91440.66 and $p=0.889$ for death: $95 \% \mathrm{Cl}: 112.66-68.96$ and $p=0.635$ for rethoracotomy).

\section{ADP test results}

The impact of the ADP test result in both groups was compared in all the 200 subjects. An ROC curve was constructed for the ADP test for a total of 200 patients (Fig. 4). The result is expressed as AUC. The units we used were $U$ (not $\mathrm{AU} / \mathrm{min}$ as reported by Weber et al. [13]), as recommended by the manufacturers in recent years $(U=A U / 10)$.

From the ROC curve, the optimal cut-off value for the ADP test was established at $26 \cup(p=0.043)$, at the sensitivity

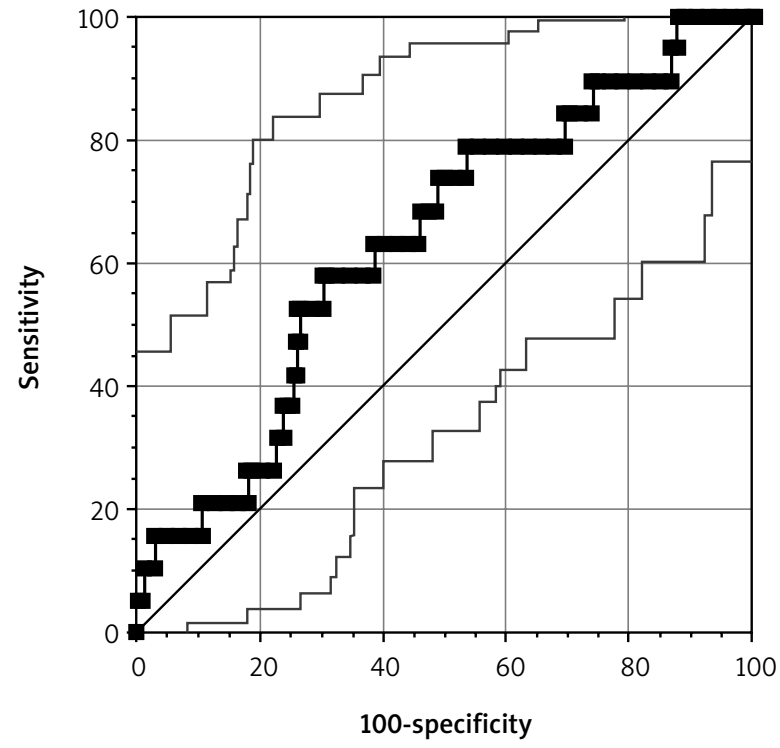

Fig. 4. The receiver operating characteristic (ROC) curve for the ADP test results of the entire study cohort $(N=200)$

of $72 \%$, specificity of $69 \%$, positive predictive value (PPV) of $69.90 \%$, and negative predictive value (NPV) of $71.13 \%$.

Logistic regression showed that an ADP test result of $<26 \mathrm{U}$ tripled the risk of the composite primary endpoint (OR 3.15; 95\% Cl: 1.20-8.26; $p=0.019$ ). Additional multivariate analysis demonstrated that an ADP test result of $<26 U$ was predictive of the composite primary endpoint regardless of age $(p=0.049)$ or $\operatorname{sex}(p=0.176)$.

Multivariate analysis also demonstrated that an ADP test result of $<26 \mathrm{U}$ was associated with an independent (and higher) predictability for the composite endpoint compared to the EuroScore ( $p=0.022$ for ADP test results of $<26 \mathrm{U}, p=0.052$ for EuroScore).

The risk of chest tube drainage output of $2000 \mathrm{ml}$ or more within the first 24 hours post-op was described by an OR of 2.07 ( $95 \% \mathrm{Cl}: 0.40-10.59 ; p=0.378$ ). 
In subjects with ADP test results of $<26 \mathrm{U}$, the risk of transfusion of 5 or more units of PRBCs within the first 24 hours post-op corresponded to an OR of $2.817(95 \% \mathrm{Cl}$ : $0.61-12.97 ; p=0.183)$. The secondary endpoint of rethoracotomy occurred in 11 subjects, and, in subjects with ADP test results of $<26 \mathrm{U}$, the estimated risk of this endpoint corresponded to OR 6.02 (95\% Cl: 1.54-23.52; $p=0.009$ ).

Three subjects undergoing surgery died. We found that the occurrence of the primary endpoint increased the risk of death (OR 18.26; 95\% Cl: 0.89-1.26; $p=0.024$ ).

Student's $t$-test showed a statistically significant difference in the ADP test results between the subjects on SAPT and the subjects on DAPT ( $52 \mathrm{U}$ vs. $28 \mathrm{U}$, respectively; $p<0.004)$.

The interaction test demonstrated that the type of antiplatelet therapy (SAPT vs. DAPT) did not modify the correlations between the ADP test results and the endpoints in a significant manner.

\section{Discussion}

Quantitative assessment of platelet aggregation by impedance aggregometry is an effective tool for identifying patients who are at an increased risk of developing postoperative bleeding and requiring transfusions of blood and blood products.

In patients on DAPT undergoing CABG surgery, the ADP test provides an accurate preoperative prediction of bleeding, risk and our study has demonstrated the validity of the method.

In the study, we adopted the definition of postoperative bleeding consistent with the literature without referring to our institution's experiences. We measured platelet reactivity only in subjects currently on SAPT or DAPT. The subjects were not stratified by the time that had elapsed since the discontinuation of antiplatelet therapy. The study included only subjects undergoing one type of surgical procedure - isolated CABG. The analysis of the ROC curve identified a cut-off value for the ADP test, which correlated with the secondary endpoints of the bleeding definition.

The difference in the number of transfused units of PRBCs (60 units in SAPT group vs. 73 units in DAPT group: $p=0.071)$ and FFP (91 units in SAPT group vs. 92 units in DAPT group: $p=1.000$ ) was not statistically significant. A statistically significant difference was, however, found in the number of transfused units of PLT concentrate (56 units in SAPT group vs. 92 units in DAPT group, $p=0.026)$. Pearse et al. have shown decreases in the incidence of PRBC $(47.3 \%$ vs. $32.4 \% ; p<0.0001)$ and platelet transfusion (36.1\% vs. $13.5 \% ; p<0.0001)$ [14]. Corredor et al. showed decreases in the incidence of PRBC (OR 0.86; 95\% Cl: 0.78-0.94; $p=0.001$ ) and FFP transfusion (OR 0.42; 95\% Cl: 0.30-0.59; $p=0.001$ ) [15]. A proportion study assessing the use of Multiplate tests for the prediction of the postoperative bleeding risk was conducted by Ranucci et al. [16]. This retrospective analysis demonstrated a correlation between the ADP test results and postoperative bleeding. A non-linear regression plot of the ADP test results relative to the postoperative drainage output was obtained. The cut-off value for the ADP test was determined to be $31 \mathrm{U}$ with a sensitivity of $72 \%$ and a specificity of $66 \%$. PPV was $29 \%$, and NPP was $92 \%$. Subjects with ADP test results below $31 \mathrm{U}$ demonstrated statistically significant postoperative bleeding and required more RBC transfusions. Interestingly, major postoperative bleeding occurred in $31.8 \%$ of subjects with results exceeding $31 \mathrm{U}$. Conversely, in the AUC < $31 \mathrm{U}$ group, postoperative bleeding occurred in $28.6 \%$ of subjects. Of note is the fact that all the subjects in the analysis discontinued CLO at least 5 days before surgery. In our view, this study has several limitations. First of all, all the surgeries involved CPB. Secondly, the subjects were undergoing various surgeries: $71 \%$ underwent bypass grafting only, 14\% - valvular heart disease surgery, and 9\% - complex surgeries (valvular and CABG surgery). The third limitation is the fact that postoperative haemorrhage was defined as $>$ the $90^{\text {th }}$ percentile of the postoperative drainage value of the author's centre [16]. It was, therefore, not defined on the basis of the criteria referred to in our study.

Petricevic et al. published a study on the use of impedance aggregometry assays solely in coronary surgery [17]. A total of 211 patients were divided into 4 groups: ASA alone, ASA plus CLO, CLO alone, and no antiplatelet therapy. Each ASPI and ADP test result was classified to one the four pre-specified ranges. The study demonstrated a statistically significant correlation between postoperative drainage and results of the ASPI and ADP tests in the groups with the lowest values. Moreover, the ASPI test result correlated with the number of transfused units of blood and blood products. The study showed that the time since the discontinuation of CLO did not correlate with the ADP test results. All surgeries involving CPB and off-pump procedures formed an exclusion criterion. The amount of postoperative drainage was considered significant if it exceeded the $75^{\text {th }}$ percentile of the results of surgical procedures in the author's institution. As in the previous analysis, there were no clearly defined postoperative haemorrhage criteria. No predictive values of the ASPI test or the ADP test in predicting major postoperative bleeding were obtained.

\section{Conclusions}

The results show a positive association between the Multiplate aggregometry results and the development of bleeding complications in subjects on SAPT or DAPT undergoing CABG surgery.

In patients on antiplatelet therapy, an ADP test result of $<26 \mathrm{U}$ is strongly predictive of serious bleeding complications after CABG surgery.

We also observed a correlation between the ADP test result and the development of complications that was independent of whether the patient was on SAPT or DAPT.

Consistently with these results, we found that, in patients on antiplatelet drugs until surgery, a result of perioperative platelet testing with the ADP test $<26 \mathrm{U}$ was a strong predictor of bleeding. The ADP test enables identification of a group of patients at an increased risk of postoperative bleeding. 


\section{Limitations}

Our study was a prospective, non-randomised, single-centre observational study. The decisions to perform blood and blood product transfusions and to perform reexploration were not based on the results of platelet function tests. Furthermore, all the surgical procedures, both on-pump and off-pump, were performed by different surgeons. Although haemostasis was achieved with standard surgical methods, the decision to proceed with re-exploration was in each case made individually by the operator. Another limitation was the fact that the TRAP test was not included. The TRAP test is normally intended for patients treated with GPIIb/IIla receptor antagonists, and treatment with these agents was an exclusion criterion in our study. In the absence of GPIIb/IIla receptor antagonists, the TRAP test measures the "natural" ability of platelets to aggregate and may be used as a tool for predicting bleeding in patients not on antiplatelet therapy (control group). As our research hypothesis pertained to patients on antiplatelet therapy only, we decided not to include the TRAP test in our study. The last limitation was the lack of postoperative measurement of platelet aggregation, particularly in subjects with signs of bleeding. Although, as already mentioned, measurement of platelet function is not a standard diagnostic procedure in cardiac surgery departments, it could be helpful in treatment decisions in patients with higher postoperative drainage.

\section{Disclosure}

Authors report no conflict of interest.

\section{References}

1. Montalescot G, Sechtem U, Achenbach S, Andreotti F, Arden C, Budaj A, Bugiardini R, Crea F, Cuisset T, Di Mario C, Ferreira JR, Gersh BJ, Gitt AK, Hulot JS, Marx N, Opie LH, Pfisterer M, Prescott E, Ruschitzka F, Sabaté M, Senior R, Taggart DP, van der Wall EE, Vrints CJM. Wytyczne Europejskiego Towarzystwa Naukowego ESC dotyczące postępowania w stabilnej chorobie wieńcowej 2013 r. Grupa robocza ESC do spraw postępowania w stabilnej chorobie wieńcowej. Kardiol Pol 2013; 71, supl. 10: 243-318.

2. Kuliczkowski W, Witkowski A, Watała C, Filipiak KJ, Budaj A, Golański J, Sitkiewicz D, Pręgowski J, Górski J, Zembala M, Opolski G, Poloński L. Stanowisko grupy Roboczej powołanej przy Sekcji Interwencji Sercowo-Naczyniowych Polskiego Towarzystwa Kardiologicznego na temat zjawiska tzw. „oporności na doustne leki przeciwpłytkowe”. Kardiol Pol 2008; 66: 480-485.

3. Sibbing D, Schulz S, Braun S, Morath T, Stegherr J, Mehilli J, Schömig A, von Beckerath N, Kastrati A. Antiplatet effects of clopidogrel and bleedning in patients undergoing coronary stent placement. J Tromb Haemost 2010; 8: 250-256.
4. Sibbing D, Steinhubl SR, Schulz S, Schömig A, Kastrati A. Platelet aggregation and its association with stent thrombosis and bleeding in clopidogreltreated patients: initial evidence of a therapeutic window. J Am Coll Cardiol 2010; 56: 317-318

5. Angiollillo DJ, Fernandez-Ortiz A, Bernardo E, Alfonso F, Macaya C, Bass TA, Costa MA. Variability in individual responsiveness to clopidogrel: clinical implications, management, and future perspectives. J Am Coll Cardiol 2007; 49: 1505-1516.

6. Ferreiro JL, Angiolillo DJ. Clopidogrel response variability: current status and future directions. Thromb Haemost 2009; 102: 7-14.

7. Meyer Rahe N, Winterhalter M, Boden A, Froemke C, Piepenbrock S, Calatzis A, Solomon C. Platelet concentrates transfusion in cardiac surgery and platelet function assessment by multiple electrode aggregometry. Acta Anaesthesiol Scand 2009; 53: 168-175.

8. Kohl P, Danhin N, Di Mario C, et al. Wytyczne ESC dotyczące rewaskularyzacji mięśnia sercowego z 2010 r. Grupa Robocza Europejskiego Towarzystwa Kardiologicznego (ESC) do spraw rewaskularyzacji mięśnia sercowego oraz Europejskie Stowarzyszenie Chirurgii Serca i Klatki Piersiowej (EACTS). Kardiol Pol 2010; 68 supl. 8: 569-638.

9. Hanke A, Roberg K, Monaca E, Sellmann T, Weber CF, Rahe-Meyer N, Görlinger K. Impact of platelet count on results obtained from multiple electrode platelet aggregometry (Multiplate). Eur J Med Res 2010; 15: 214-219.

10. Tóth O, Calatzis A, Penz S, Losonczy H, Siess W. Multiple electrode aggregometry: a new device to measure platelet aggregation in whole blood. Thromb Haemost 2006; 96: 781-788.

11. Ferreiro JL, Sibbing D, Angiolillo DJ. Platelet function testing and risk of bleeding complications. J Thromb Haemost 2010; 103: 1128-1135.

12. Mehran R, Rao Sunil V, Bhatt DL, Gibson CM, Caixeta A, Eikelboom J, Kaul S, Wiviott SD, Menon V, Nikolsky E, Serebruany V, Valgimigli M, Vranckx P, Taggart D, Sabik JF, Cutlip DE, Krucoff MW, Ohman EM, Steg PG, White H. Standardized bleeding definitions for cardiovascular clinical trials: a consensus report from Bleeding Academic Research Consortium. Circulation 2011; 123: 2736-2747.

13. Weber CF, Görlinger K, Meininger D, Herrmann E, Bingold T, Moritz A, Cohn LH, Zacharowski K. Point-of-care testing: a prospective, randomized clinical trial of efficacy in coagulopathic cardiac surgery patients. Anesthesiology 2012; 117: 531-547.

14. Pearse BL, Smith I, Faulke D, Wall D, Fraser JF, Ryan EG, Drake L, Rapchuk IL, Tesar P, Ziegenfuss M, Fung YL. Protocol guided bleeding managemet improves cardiac surgery patient outcomes. Vox Sang 2015; 109: 267-279.

15. Corredor C, Wasowicz M, Karkouti K, Sharma V. The role of point-of-care platelet function testing in predticting postoperative bleeding following cardiac surgery: a systematic review and meta-analysis. Anaesthesia 2015; 70: 715-731.

16. Ranucci M, Baryshnikova E, Soro G, Ballotta A, De Benedetti D, Conti D; Surgical and Clinical Outcome Research (SCORE) Group. Multiple electrode whole blood aggregometry and bleeding in cardiac surgery patients receiving thienopyridines. Ann Thorac Surg 2011; 91: 123-130.

17. Petricevic M, Biocina B, Milicic D, Konosic S, Ivancan V, Milosevic M, Burcar I, Gasparovic H. Bleeding risk assessment using multiple electrode aggregometry in patients following coronary artery bypass surgery. J Thromb Thrombolysis 2013; 35: 31-40. 